\title{
CCNH Gene
}

National Cancer Institute

\section{Source}

National Cancer Institute. CCNH Gene. NCI Thesaurus. Code C89766.

This gene plays a role in both basal transcription control and the cell cycle. 